Check for updates

Cite this: RSC Med. Chem., 2021, 12, 779

Received 29th October 2020

Accepted 25th March 2021

DOI: $10.1039 / \mathrm{d} 0 \mathrm{md} 00366 \mathrm{~b}$

rsc.li/medchem

\title{
The modulatory role of sulfated and non-sulfated small molecule heparan sulfate-glycomimetics in endothelial dysfunction: absolute structural clarification, molecular docking and simulated dynamics, SAR analyses and ADMET studies $\dagger$
}

\author{
Daniel M. Gill, ${ }^{a}$ Ana Paula R. Povinelli, ${ }^{\text {ab }}$ Gabriel Zazeri, ${ }^{\text {ab }}$ Sabrina A. Shamir, ${ }^{c}$ \\ Ayman M. Mahmoud, (D) def Fiona L. Wilkinson, ${ }^{f}$ M. Yvonne Alexander, ${ }^{f}$ \\ Marinonio L. Cornelio ${ }^{b}$ and Alan M. Jones iD *a
}

\begin{abstract}
The conceptual technology of small molecule glycomimetics, exemplified by compounds C1-4, has shown promising protective effects against lipid-induced endothelial dysfunction, restorative effects on diabetic endothelial colony forming cells, and preventative effects on downstream vascular calcification amongst other important in vitro and ex vivo studies. We report the optimised synthesis of an array of 17 small molecule glycomimetics, including the regio-, enantio- and diastereo-meric sulfated scaffolds of a hit structure along with novel desulfated examples. For the first time, the absolute stereochemical configurations of C1-4 have been clarified based on an identified and consistent anomaly with the Sharpless asymmetric dihydroxylation reaction. We have investigated the role and importance of sulfation pattern, location, regioisomers, and spatial orientation of distal sulfate groups on the modulation of endothelial dysfunction through their interaction with hepatocyte growth factor (HGF). In silico studies demonstrated the key interactions the persulfated glycomimetics make with HGF and revealed the importance of both sulfate density and positioning (both point chirality and vector) to biological activity. In vitro biological data of the most efficient binding motifs, along with desulfated comparators, support the modulatory effects of sulfated small molecule glycomimetics in the downstream signaling cascade of endothelial dysfunction. In vitro absorption, distribution, metabolism, elimination and toxicity (ADMET) data demonstrate the glycomimetic approach to be a promising approach for hit-to-lead studies.
\end{abstract}

\section{Introduction}

The endothelium plays a crucial role in the regulation of vascular haemostasis, vascular tone, thrombosis and thrombolysis. ${ }^{1}$ Endothelial dysfunction (ED) has been associated with the increased risk of atherosclerosis and cardiovascular

${ }^{a}$ School of Pharmacy, University of Birmingham, Edgbaston, B15 2TT, UK.

E-mail: a.m.jones.2@bham.ac.uk; Tel: +44(0)1214147288

${ }^{b}$ Departamento de Física - IBILCE, Rua Cristovão Colombo, 2265 CEP 15054-00o

São José do Rio Preto, São Paulo, Brazil

${ }^{c}$ Department of Natural Sciences, Manchester Metropolitan University, M1 5GD, UK

${ }^{d}$ Physiology Division, Department of Zoology, Faculty of Science, Beni-Suef

University, Egypt

${ }^{e}$ Department of Endocrinology, Diabetes \& Nutrition, Center for Cardiovascular Research (CCR), Charité - Universitätsmedizin Berlin, Berlin, Germany

${ }^{f}$ Centre for Biomedicine, Manchester Metropolitan University, M1 5GD, UK

$\dagger$ Electronic supplementary information (ESI) available: Compound characterisation, ${ }^{1} \mathrm{H}$ and ${ }^{13} \mathrm{C}$ NMR spectra, docking studies, crystallographic data for 22 and biological assays. CCDC 2038360. For ESI and crystallographic data in CIF or other electronic format see DOI: 10.1039/d0md00366b complications, ${ }^{2}$ characterized by the reduced bioavailability of the vasodilator nitric oxide (NO) and increased levels of reactive oxygen species (ROS). ${ }^{3}$ Elevation in the level of free fatty acids (FFA) in the blood plasma has been implicated as an associated factor for the destruction of the endothelium, partly due to the enhanced production of ROS, which in turn reduces the availability of intracellular NO. ${ }^{4}$ Activation of NADPH oxidase by FFA leads to the deactivation of endothelial nitric oxide synthase (eNOS) and the down-regulation of the protective pathways. ${ }^{5}$

Examples of endothelial modulators are shown in Fig. 1, including the polysaccharide-based glycomimetic Equitend, ${ }^{6}$ an analogue of prostacyclin Iloprost ${ }^{7}$ and chalcone derivative 1m-6. ${ }^{8}$ Our approach uses glycomimetics-small molecules that are designed to mimic the function of polysaccharide based biomolecules-and serve as an attractive therapeutic technology in a wide range of diseases. ${ }^{9,10}$ Recent advances of the glycomimetic approach have included the development of selective carbonic anhydrase inhibitors; ${ }^{11}$ and the use of highly sulfated glycomimetics as inhibitors of viral binding. ${ }^{12}$ 

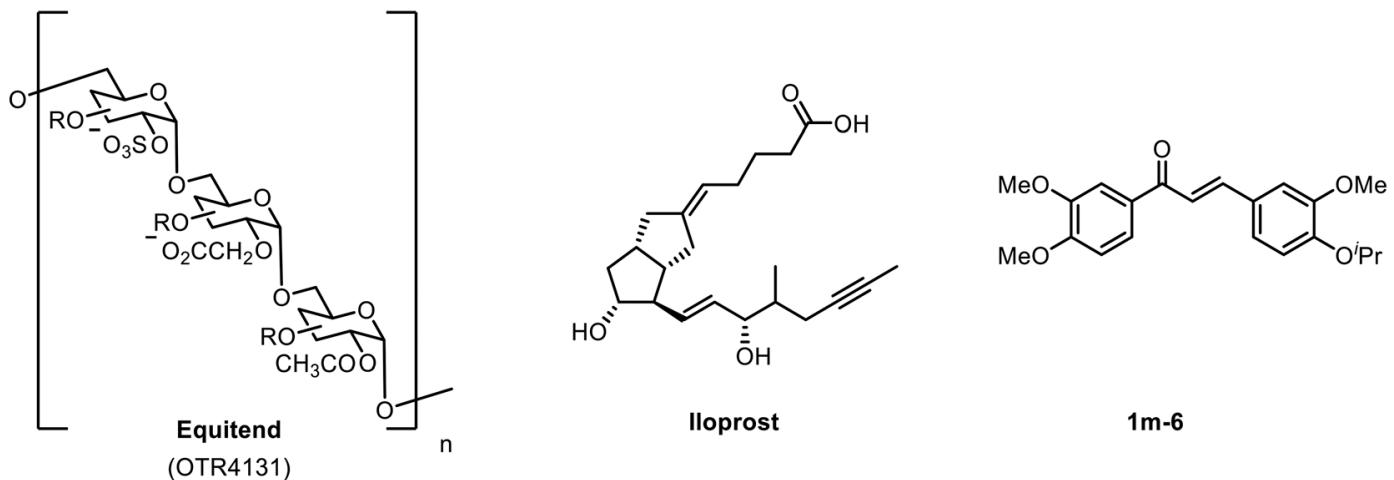

Fig. 1 Molecular scaffold approaches to modulating endothelial dysfunction.

The first generation glycomimetics (C1-C4, Fig. 2a), were originally designed as inhibitors of hepatocyte growth factor/ scatter factor (HGF/SF)-induced hepatocyte growth factor receptor (c-Met) activation, affecting tumour cell growth and angiogenesis. ${ }^{13}$ It should be noted that the findings of the present work indicate that the original discovery experiments $^{13}$ were likely performed with ambiguous mixtures of these glycomimetics.

It was subsequently found that $\mathbf{C 1 - C 4}$ are superior to attenuate lipid-induced endothelial dysfunction and regenerating eNOS activity. ${ }^{14}$ We have also recently disclosed that our aryl templated, small molecule heparan sulfateglycomimetics modulate vascular calcification ${ }^{15}$ and diabetic endothelial colony forming cells in vitro. ${ }^{16}$

Hepatocyte growth factor $\mathrm{HGF} / \mathrm{c}-\mathrm{Met}$ signalling has been reported to affect vascular calcification, an end point of endothelial dysfunction in the atherosclerotic spectrum. ${ }^{17}$ Heparan sulfate acts as a ligand for activation of the HGF/cMet signalling pathway, thus one can attenuate this pathway using small molecule heparan sulfate-glycomimetics and reduce vascular calcification as a risk factor for cardiovascular diseases. The downstream signalling of HGF/ c-Met modulates the phosphoinositide 3-kinase/protein kinase B (PI3K/Akt) pathway leading to the production of the biomarker nitric oxide (NO) via eNOS which has restorative effects on damaged endothelial cells. ${ }^{14}$

Herein, we report the structural clarification, and the optimised modular synthesis of small molecule heparan sulfate-glycomimetics, with molecular docking and dynamics of their interaction with HGF. The biological evaluation of small molecule glycomimetics as modulators for endothelial dysfunction combined with ADMET results demonstrate the concept of this new technology in glycomimetic design.

\section{Results and discussion}

\section{An improved synthesis of C1-C4}

Initially, we sought to prepare the first generation glycomimetics (C1-C4, Fig. 2a) as a route to access both sulfated and non-sulfated analogues for a parallel biological evaluation. The knowledge gained from the results of our previously described chiral HPLC study, investigating the tandem Sharpless asymmetric dihydroxylation (AD) on diene 1, provided evidence for the stereochemical configurations of glycomimetics $\mathbf{C} 1$ and $\mathbf{C} 2$ (Fig. 2b/Scheme 1). ${ }^{18}$ The chiral HPLC results highlighted that the tetraol precursors ( $\alpha-2$ and $\beta-2$ ) contain mixtures of diastereo- and enantio-meric pairs, and importantly the stereochemistry of the major diastereomeric species is reversed in comparison to the original literature report. ${ }^{13}$ The stereochemistry of the originally assigned tetraols and subsequent glycomimetics from the original report ${ }^{13}$ were clarified (Fig. 2b and Scheme 1). The persulfation of all tetraol intermediates was carried out using the TBSAB-sulfation methodology $^{19-21}$ (Scheme 1), specifically, the use of this reagent afforded the heparan sulfate-glycomimetics $\alpha-\mathbf{4}$ (C1) and $\beta-5$ (C2) in $88 \%$ and $86 \%$ yield, respectively.

The synthesis of diols $R-\mathbf{1 0}$ and $S$-10 were adapted from the original report ${ }^{13}$ (Scheme 2). With alkene 7 in hand, $A D$ reactions were performed with Sharpless formulations $\alpha$ and $\beta$ under standard conditions, ${ }^{22}$ affording diols $S$-8 and $R-8$ in 99\% yield (Scheme 2). A chemoselective hydrolysis of the acetate functionality using $\mathrm{K}_{2} \mathrm{CO}_{3}$ in methanol afforded triols $S$-9 and $R$-9 in 99\% yield. Persulfation of the triols with TBSAB afforded the first-generation heparan sulfateglycomimetics $R \mathbf{- 1 0}$ (previously known as $\mathbf{C 3}$ ) and $S$-10 (previously known as C4) in $72 \%$ and $97 \%$ yield, respectively.

Asymmetric induction in the $\mathrm{AD}$ has been demonstrated to work effectively at the meta position alkene in $7 .^{18}$ Therefore this investigation was confident that the desired enantiomers were synthesized in a large enantiomeric excess. However, to further confirm the stereochemistry of these enantiomers, the synthesis of enantiomer $S$-9 was prepared using a chiral pool method (Scheme 3), and the optical rotations of prepared $S$-9 (Scheme 2) and authentic chiral pool $S$-9 were compared.

The optical rotations correlated with the predicted stereochemical configuration, and the closely matching values $\left(-7.01\right.$ vs. -8.67 , c 1.0 in $\mathrm{CHCl}_{3}$ ) confirmed that the correct enantiomer was synthesised with a calculated 91:9e. $r(S / R)$ (Scheme 3). Furthermore, the stereochemical configurations of the triols $\mathbf{9}$ and resulting heparan sulfateglycomimetics $\mathbf{1 0}$ also opposed the assigned stereochemistry from the original report ${ }^{13}$ (Fig. 2a). 


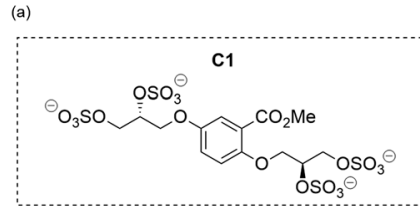

(b)

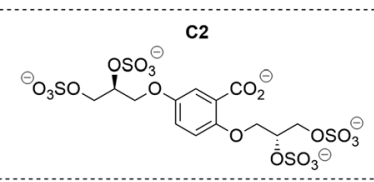

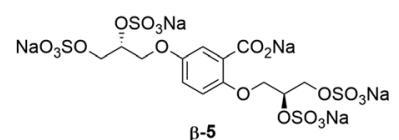

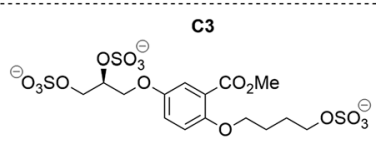

$$
\overbrace{\mathrm{O}_{3} \mathrm{SO}}^{\mathrm{OSOO}_{3}^{\ominus}}
$$

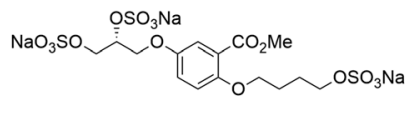

$R-10$

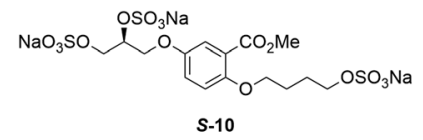

Fig. 2 (a) Originally proposed stereoisomers of $\mathrm{C} 1-\mathrm{C} 4{ }^{13}$ and (b) clarification of the stereochemical outcomes for $\mathrm{C} 1-\mathrm{C} 4$ from this work.

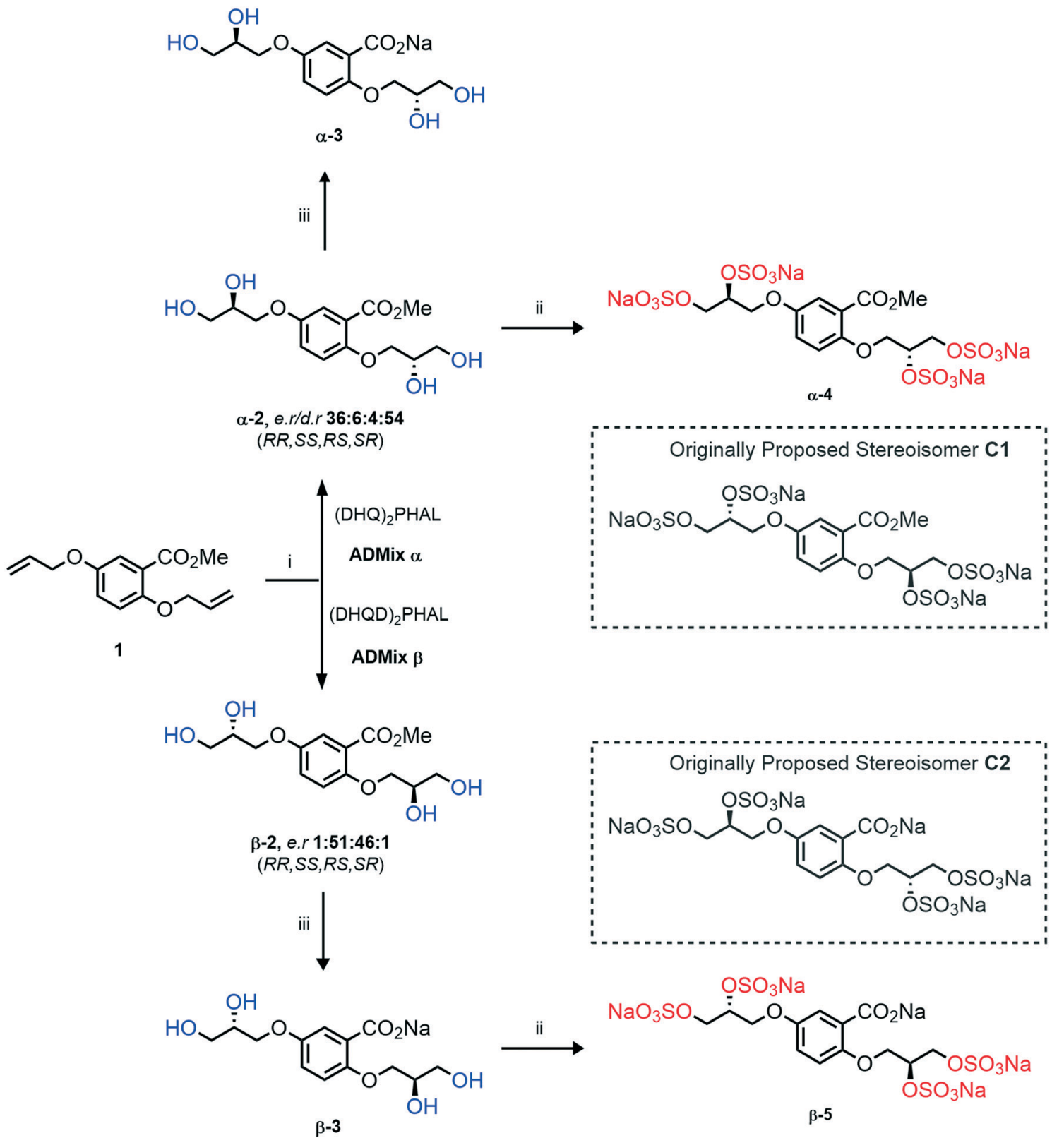

Scheme 1 The synthesis of first-generation heparan sulfate-glycomimetics $\alpha-4$ (C1) and $\beta-5$ (C2), including biologically relevant intermediates considered in this investigation. Conditions: i) $\mathrm{K}_{2} \mathrm{CO}_{3}, \mathrm{~K}_{3} \mathrm{Fe}(\mathrm{CN})_{6}, \mathrm{~K}_{2} \mathrm{OsO}_{2}(\mathrm{OH})_{4},{ }^{t} \mathrm{BuOH} / \mathrm{H}_{2} \mathrm{O}, 0{ }^{\circ} \mathrm{C}, 12 \mathrm{~h}, 99 \%$ for both; ii) TBSAB, $\mathrm{MeCN}, 90{ }^{\circ} \mathrm{C}, 8 \mathrm{~h}$ $88 \%$ and $86 \%$ for $\alpha-4$ and $\beta-5$, respectively; iii) $\mathrm{NaOH}, \mathrm{MeOH}, 70{ }^{\circ} \mathrm{C}, 2 \mathrm{~h} 99 \%$ for both. 

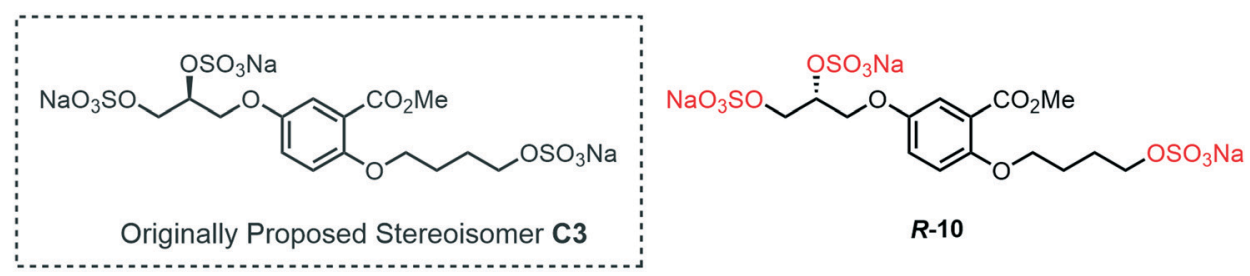

$R-10$

v<smiles>CC(=O)OCCCCOc1ccc(OC[C@H](O)CO)cc1C(C)=O</smiles><smiles>CC(=O)c1cc(OC[C@@H](O)CO)ccc1OCCCCO</smiles>

$S-8$

S-9<smiles>C=CCOc1ccc(O)c(C(=O)[O-])c1</smiles>

6<smiles>C=CCOc1ccc(OCCCCOC(C)=O)c(C(C)=O)c1</smiles>

7

iii<smiles>CC(=O)OCCCCOc1ccc(OCC(O)CO)cc1C(C)=O</smiles>

$R-8$<smiles>CC(=O)c1cc(OCC(O)CO)ccc1OCCCCO</smiles>

$R-9$

v
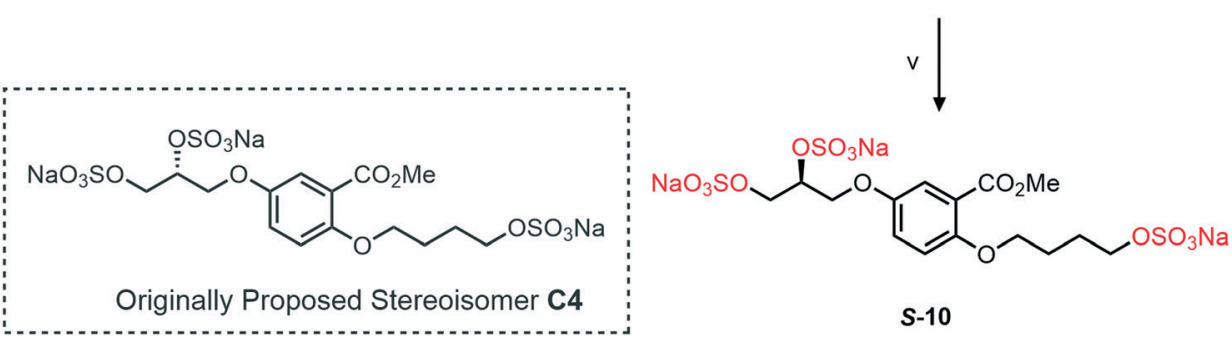

Scheme 2 The synthesis of heparan sulfate-glycomimetics $S-10$ (C4) and $R-10$ (C3). Conditions: i) 4-bromobutylacetate, $\mathrm{K}_{2} \mathrm{CO}_{3}, \mathrm{TBAl}$, acetone, reflux, $12 \mathrm{~h}, 90 \%$, ii) $\mathrm{ADmix} \beta,{ }^{\mathrm{t}} \mathrm{BuOH} / \mathrm{H}_{2} \mathrm{O}, 0{ }^{\circ} \mathrm{C}, 12 \mathrm{~h}, 99 \%$ for both; iii) $\mathrm{ADmix} \alpha,{ }^{t} \mathrm{BuOH} / \mathrm{H}_{2} \mathrm{O}, 0{ }^{\circ} \mathrm{C}, 12 \mathrm{~h}, 99 \%$ for both; iv) $\mathrm{K}_{2} \mathrm{CO}, \mathrm{MeOH}_{3}, \mathrm{rt}, 12 \mathrm{~h}$, $99 \%$ for both; v) TBSAB, MeCN, $90{ }^{\circ} \mathrm{C}, 12 \mathrm{~h}, 72 \%$ and $97 \%$ for $R-10$ and $S-10$, respectively.

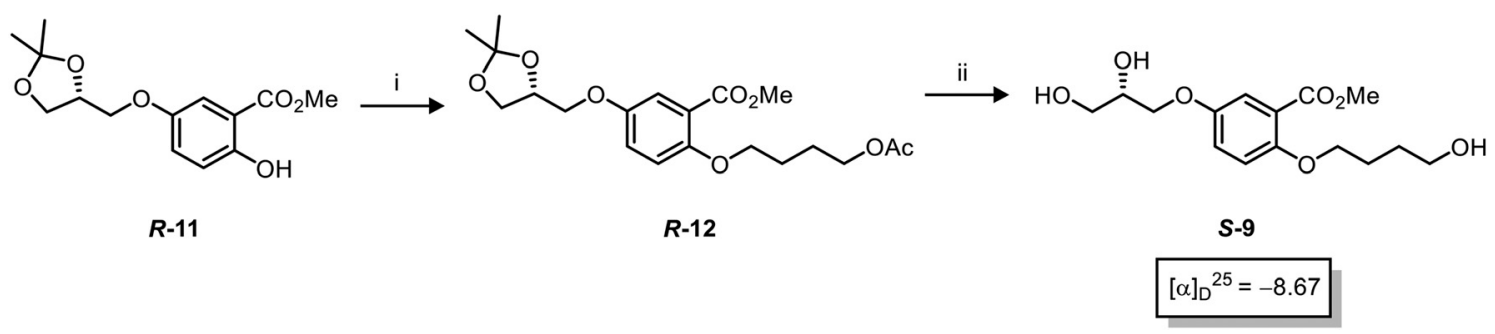

Scheme 3 A chiral pool synthesis of S-9 for the comparison of optical rotation. Conditions: i) 4-bromobutylacetate, $\mathrm{K}_{2} \mathrm{CO}_{3}, \mathrm{TBAl}$, acetone, reflux, $12 \mathrm{~h}, 90 \%$, ii) 1) $\mathrm{NaOMe}, \mathrm{MeOH}, 2) \mathrm{TFA}, \mathrm{MeOH}, 12$ h, $99 \%$.

Overall, this investigation has assigned the correct stereochemistry to all previously reported heparan sulfate- glycomimetics (C1-C4) and provided a practical and efficient synthesis to the final target structures. 


\section{In silico studies}

A computational approach was used to triage the key modified compounds based on $\alpha \mathbf{- 4}$ as the prototypical firstgeneration small molecule glycomimetic, to take forward for biological evaluation and in vitro ADMET studies.

The computational model was built based on the X-ray crystal structures of NK1-HGF (PDB: 1BHT, 2.0 resolution). ${ }^{23}$ Each heparan sulfate-glycomimetic and nonsulfated intermediate was docked individually against 1BHT under matching conditions and each minimum docking energy was calculated. ${ }^{24}$

Molecular docking ranked the glycomimetics according to their affinities toward the NK1-heparin binding site (Table S3†). MM/PBSA calculations were performed along with molecular dynamics to obtain a more accurate prediction of binding free energy of the active candidates. Such techniques incorporate conformational fluctuations, entropic contributions, and solvent molecules interactions, which are not considered by molecular docking that is based on simple energetic and geometric criteria. The glycomimetic binding energies were rescored based on MM/PBSA, as summarised in Table S3.† The exploration of detailed energy composition obtained from MM/PBSA, revealed that the predominant interaction of a negatively charged glycomimetic toward $\mathrm{N}$-domain of the protein is electrostatic in nature. Not surprisingly, the microenvironment of interaction disclosed by docking is largely composed by positively charged amino acids residues of: Arg73 and Lys78, 58, 60, 62, 63, and 78 (Fig. S1†).

Interestingly, the docked structure of the $\alpha-4-\mathrm{HGF}$ complex (Fig. 3A) shows that the methyl ester is orientated directly into a hydrophobic pocket on the protein's accessible surface (Fig. 3B). Comparing this interaction to the $\beta-\mathbf{5}-\mathrm{HGF}$ complex (Fig. S1 $\dagger$ ) indicates that this mode of binding is specific to the methyl ester group (present in heparan sulfateglycomimetics $\alpha-\mathbf{4}, \quad R-\mathbf{1 0}$, and $S-\mathbf{1 0})$, and the anionic carboxylate group (present in heparan sulfate-glycomimetic $\beta-5)$ is orientated differently inside the heparan sulfatebinding site of HGF. This interaction is not gained through further electrostatic forces and is likely driven by enhanced hydrogen bonding and van der Waals forces. Consequently, the methyl ester is considered important to the design of a second generation of heparan sulfate-glycomimetics.

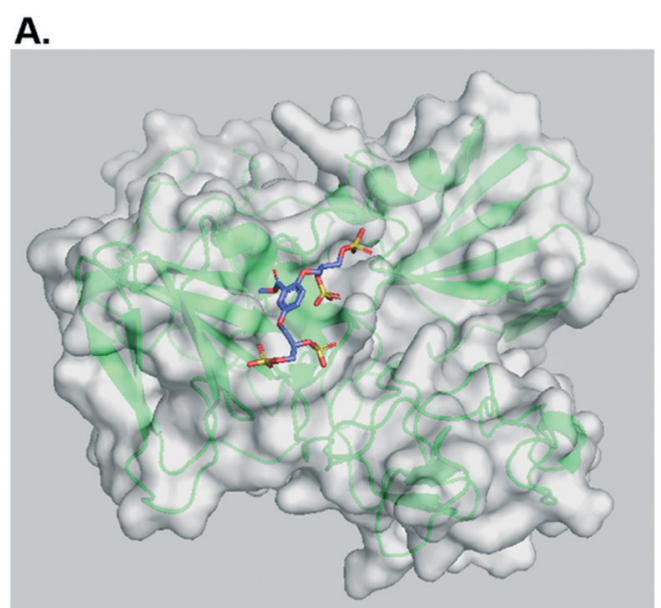

B.

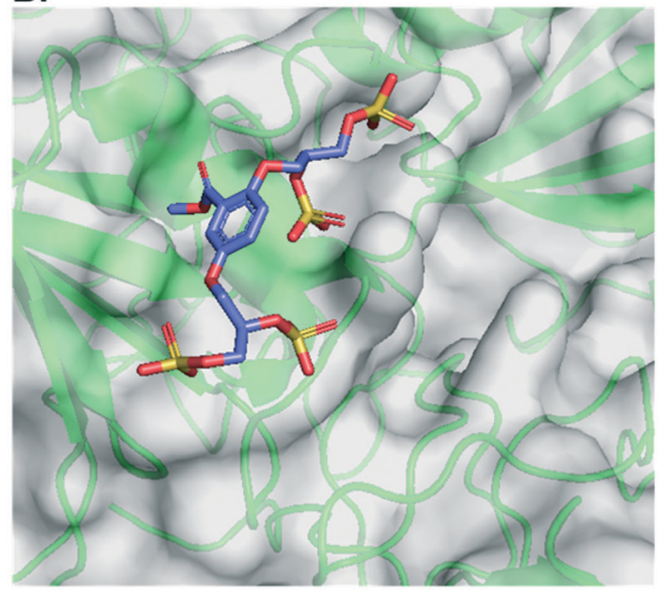

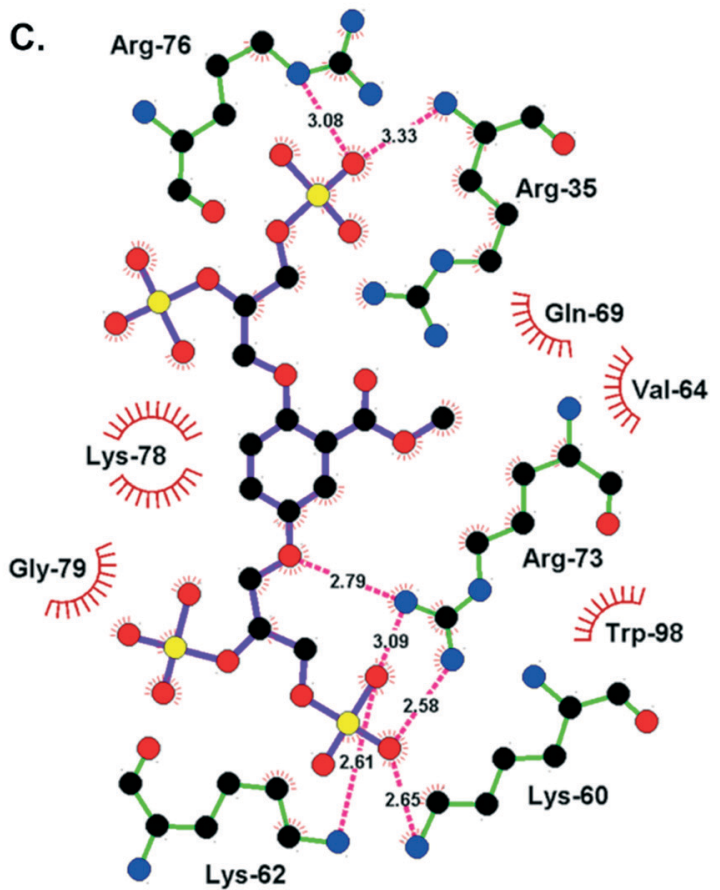

Fig. 3 A) The minimum energy docked structure of heparan sulfate-glycomimetic $\alpha-4$ into the heparan sulfate-binding site of NK1 (HGF), Table 1, entry 3; B) zoomed in view of the docked structure. Key: amino acids are represented as green ribbons and polar surface area is opaque white; C) Ligplot representation of individual binding interactions displaying vicinal amino acid residues and hydrogen bonds. 


\section{Computational SAR around prototypical glycomimetic 4}

The first generation glycomimetics included a modified linear linker at the 2-position, and comparison with $\alpha-\mathbf{4}$ showed a modest loss of affinity $(R \mathbf{- 1 0}-41.0$ or $S-\mathbf{1 0}-42.0$ vs. $\alpha-\mathbf{4}-47.4 \mathrm{~kJ} \mathrm{~mol}^{-1}$ (Table 1)). The molecules $\alpha-\mathbf{4}, \beta-5$ and 26 presented the greatest binding energy values and therefore the highest affinity for the HGF/NK1 binding site. Moreover, the results showed that the binding sites are composed mainly by charged and polar amino acids and that electrostatic interaction and hydrogen bonding interactions dominate. Both $\alpha-\mathbf{4}$ and $\beta-\mathbf{5}$ presented a considerable number of hydrogen bonds with the amino acids at Lys60, Lys62, and Arg73, ( $\beta-5$ also had further interactions with Gln69 and Thr61) (Fig. S1 $\dagger$ ). These results indicated that $\alpha-\mathbf{4}$ and $\beta-5$ are the most promising molecules to bind HGF-NK1, as they have both high affinity to the binding site and provided high stability to the resulting complex formed. In summary, it was shown that the sulfate groups present in $\alpha-\mathbf{4} / \beta-\mathbf{5}$ are essential to high affinity of the glycomimetic scaffold to the binding site from an energetic perspective.

In the case of the desulfated $\alpha-2$, four hydrogen bonds were observed with Lys58 and Ala56, such interactions likely play an important role in the stabilization of the complex formed by $\alpha-2$ and unlike the other molecules $\alpha-2$ had a stronger influence through van der Waals interactions than electrostatic.

\section{Is the absolute stereochemistry critical to the binding of HGF?}

As heparan sulfate is a larger, linear polysaccharide chain containing numerous chiral centres, with some degree of flexibility of iduronic acid motifs, we considered whether the stereochemical positioning of the sulfate vectors on our more rigid aromatic core influenced the binding of the heparan sulfate-glycomimetics to HGF in silico.

A chiral pool method ${ }^{18}$ was employed to access all four possible stereochemical combinations of $\alpha \mathbf{- 4}$. Each stereodefined tetraol (Scheme 4) was in turn sulfated with TBSAB, affording the corresponding persulfated glycomimetic ( $\alpha-4)$ in $49-82 \%$ isolated yield as their tetrakis sodium salts.

A computational docking study was performed on each potential stereoisomer of $\mathbf{4}$ to determine if the binding interactions of the heparan sulfate-glycomimetics are affected by single point changes in chirality. The results of the computational docking study suggested that each stereoisomer binds to HGF with similar energies (within 2.9 $\mathrm{kJ} \mathrm{mol}^{-1}$ ). Docking results calculated that the enantiomer $2 S, 5 S$-4 to have the strongest energy binding interaction with HGF. Furthermore, the enantiomer $2 R, 5 R-\mathbf{4}$ was calculated to have the weakest binding energy. A difference of $\pm 2.9 \mathrm{~kJ}$ $\mathrm{mol}^{-1}$ suggests that non-electrostatic intermolecular forces, such as van der Waals interactions, have minimal effects on the free energy binding interaction. The diastereomers $2 S, 5 S$ -
4/2R,5S-4 have closely matched energies $\left( \pm 1.6 \mathrm{~kJ} \mathrm{~mol}^{-1}\right)$. A single point change in stereochemistry at the 2-position had an associated decrease in hydrogen bonding, suggesting a non-optimal orientation of the substituent.

Overall, the results gained by this docking study propose that the heparan sulfate-glycomimetic's binding to HGF are not substantially determined by their inherent asymmetry, which is in agreement with the near-equipotent biological results gained from the first generation of asymmetric heparan sulfate-glycomimetics, C1-C4. ${ }^{14}$

Furthermore, from the results of our initial in silico study, this investigation decided that a stereocontrolled synthesis was not imperative in the design of further generations of heparan sulfate-glycomimetics targeting HGF. Therefore, the design of a second generation of heparan sulfateglycomimetics focussed on the regioisomeric orientation of anionic sulfate groups around an aromatic core structure.

\section{Computational SAR of second generation glycomimetics}

For synthetic details of the preparation of racemic second generation regioisomeric glycomimetics see Schemes S1-S3.† To streamline the docking study of all the following second generation sulfated glycomimetics, the $n S, n S$ or $S$-enantiomers from the racemates were docked against NK1 (HGF) using a globally parametrized training set of structures. A series of point changes were made to the core structure of $\mathbf{4}$, as follows: converting the methyl ester to the carboxylic acid ( $\beta-5)$, resulted in an increased affinity $\left(\beta-5-51.4\right.$ vs. $\alpha-4-47.4 \mathrm{~kJ} \mathrm{~mol}^{-1}$, Table 1); deletion of the methyl ester, led to a modest loss of affinity (17f $\left.-45.8 v s . \alpha-4-47.4 \mathrm{~kJ} \mathrm{~mol}^{-1}\right)$. Removal of the sulfate units from either the methyl ester $(\alpha-4)$ or the carboxylic acid $(\beta-5)$, led to a dramatic loss of affinity for NK1 ( $\alpha-2-9.2$ vs. $\alpha-4$ $-47.4 \mathrm{~kJ} \mathrm{~mol}^{-1}$ and $\beta-3-19.2$ or $\alpha-3-15.8$ vs. $\beta-5-51.4 \mathrm{~kJ}$ $\left.\mathrm{mol}^{-1}\right)$.

We next considered whether the 2,5-regioisomer of the sulfated glycols around the benzoate core was optimal (Table 1). The results of this study suggest that altering the orientation of sulfate groups via the investigation of regioisomers around an aromatic framework have little effect on the binding interactions with HGF and thus the 2,5-regioisomers were progressed to further experimental evaluation.

We next considered what is driving the interaction of $\alpha-\mathbf{4}$ with HGF, is it the 2 or 5 -sulfated glycol motif (Table 1). The removal of an entire sulfated glycol side chain afforded disulfates $\mathbf{1 7} \mathbf{g}-\mathbf{i}$ (Table 1 ). The structurally smaller disulfates $17 \mathrm{~g}-\mathbf{i}(-40 \%$ by molecular mass compared to the tetrasulfates), however only an on average $-16.5 \%$ drop in binding energy, suggesting the that the disulfates are likely to be more efficient at binding HGF than the tetrasulfates $(\mathbf{1 7 a}-\mathbf{f})$. A rationale for this difference between the tetrasulfates and disulfates, is that an optimal interaction with the first disulfate chain may compromise an efficient 
Table 1 Docking scores for sulfated and non-sulfated glycomimetic analogues. Key: sulfate groups (red); alcohol groups (blue)

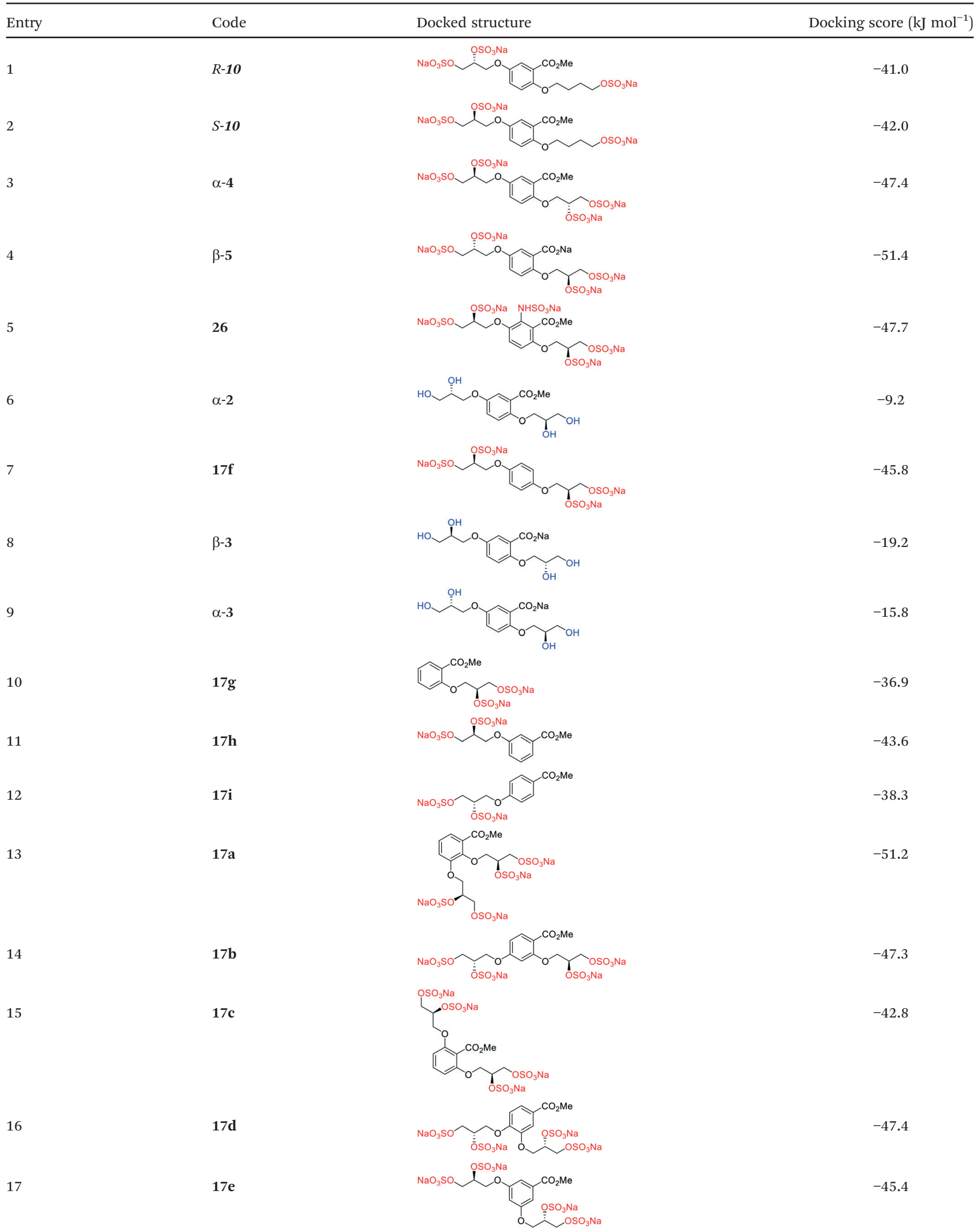




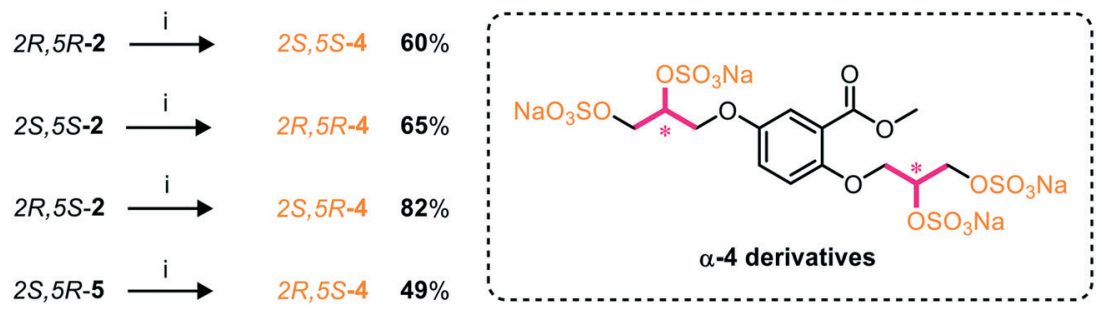

Scheme 4 A chiral pool synthesis of $\alpha-4$, synthesising each stereochemical combination. Conditions: i) 1$\left.) \mathrm{Bu}_{3} \mathrm{~N} \cdot \mathrm{SO}_{3}, \mathrm{MeCN}, 90{ }^{\circ} \mathrm{C}, 2\right)$ sodium 2-ethylhexanoate, ${ }^{t} \mathrm{BuOMe} / \mathrm{EtOH}$

binding event for the second disulfate chain at an orthosteric position.

Considering heparan sulfate has many non-sulfated regions in its macrostructure, and non-ionic interaction can account for up to $70 \%$ of the binding free energy, ${ }^{25}$ it is proposed that the interactions of endogenous heparan sulfate with HGF do not rely predominantly on anionic charge density from multiple sulfate functionalities. Taken together

(a)
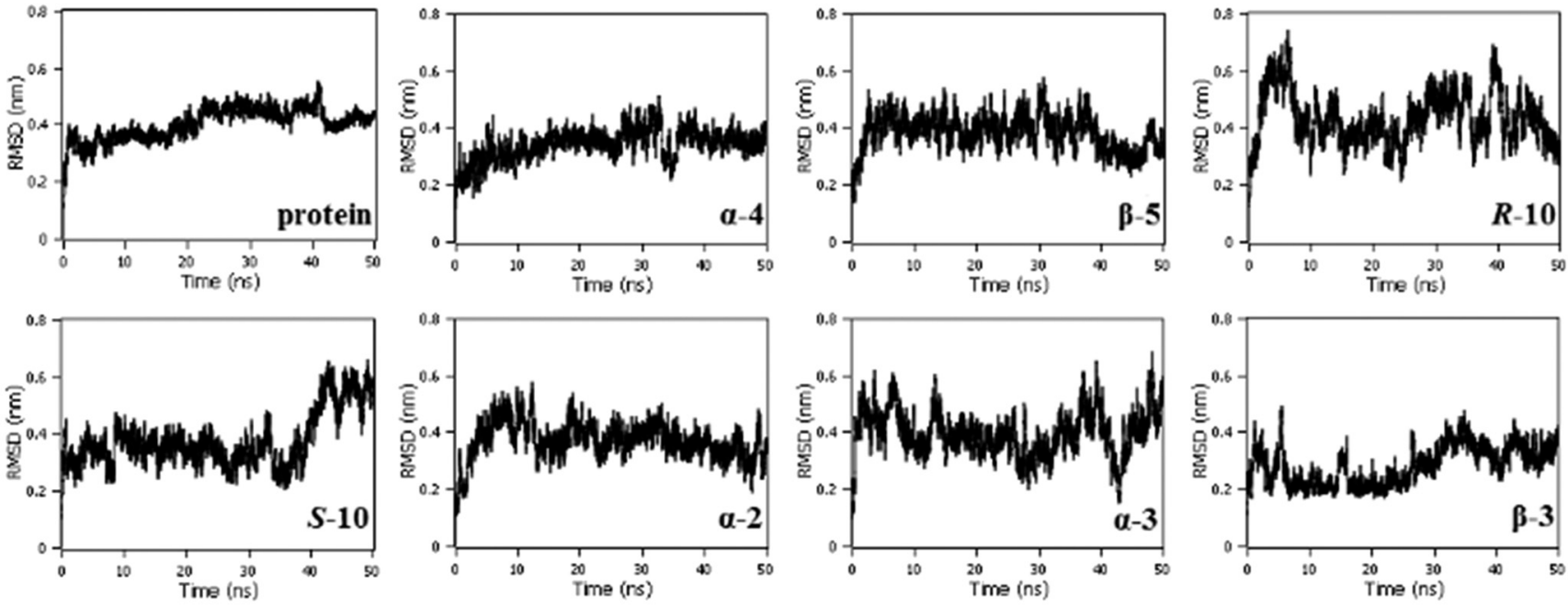

(b)
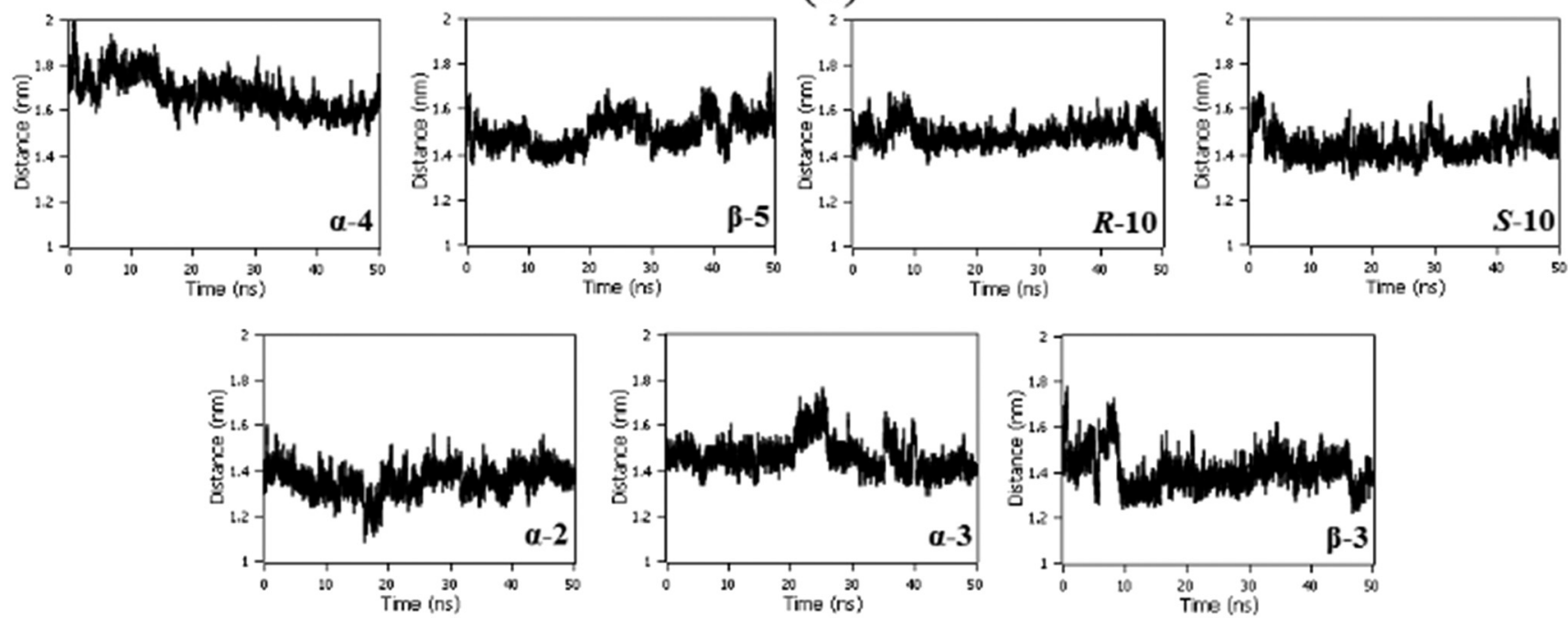

Fig. 4 (a) RMSD of the protein backbone along 50 ns of molecular dynamics in the presence of ligands: $\alpha-4 ; \beta-5 ; R-10 ; S-10 ; \alpha-2 ; \alpha-3 ;$ and $\beta-3$; (b) distance between COG of domain 1 and COG of ligands: $\alpha-4 ; \beta-5 ; R-10 ; S-10 ; \alpha-2 ; \alpha-3$; and $\beta-3$. 
these results elucidate a valuable SAR profile for the glycomimetic manifold.

Overall, the results of the computational study propose that the heparan sulfate-glycomimetics bind HGF predominantly through electrostatic interactions. However, the results also highlight the potential significance of the methyl ester and point chirality to the binding interaction of HGF.

\section{Molecular dynamic binding simulation studies of key sulfated and desulfated glycomimetics}

Root-mean-squared deviation (RMSD) analyses showed the stability of the protein structure along $50 \mathrm{~ns}$ of molecular dynamics in the presence of each triaged 2,5-regioisomeric glycomimetic scaffold investigated. It is notable that the glycomimetics did not cause any abrupt movements in the protein, indicating that NK1 remained stable in the presence of the glycomimetics. The protein remained stable after $10 \mathrm{~ns}$ of simulation in the presence of the molecules with small fluctuations (Fig. 4a). The distance between the centers of geometry (COG) of the N-domain with each glycomimetic structure remained stable with small fluctuations, indicating that the molecules remained in the binding site along $50 \mathrm{~ns}$ of molecular dynamics (Fig. 4b).

\section{Biological evaluation}

The assays focused on the production of nitric oxide (NO) and the upregulation of nitric oxide synthase (eNOS), the production of reactive oxygen species (ROS) and the activity of nicotinamide adenine dinucleotide phosphate (NADPH) oxidase (Table 2). From the hypothesised model of heparan sulfate-glycomimetic activity, ${ }^{17}$ the glycomimetics are proposed to attenuate the binding of HGF to the cMET receptor. This disruption to MET-receptor activation is proposed to modulate intracellular phosphorylation leading to an upregulation of eNOS and increased output of extracellular NO. Furthermore, the mechanism of action has also been demonstrated to modulate the enzymes: superoxide dismutase (SOD), catalase (CAT) and glutathione peroxidase (GPx), which quench intracellular ROS using NADPH as cofactor. Overall, the cross examination of NO output and reduction of ROS was used to determine the therapeutic action of the triaged glycomimetics $\alpha-\mathbf{4}, R-\mathbf{1 0}, S-\mathbf{1 0}$ and $\beta-\mathbf{5}$, as well as 3 non-sulfated intermediates $\alpha-2, \alpha-3$ and $\beta-3$, on free fatty acid (FFA) induced, oxidatively stressed endothelial cell cultures (Table 2).

The results of the biological assays demonstrate similar trends across each compound (Table 2). Administration of the heparan sulfate-glycomimetics and non-sulfated intermediates generates an increase in eNOS phosphorylation with an associated output of NO. Furthermore, each compound demonstrated a correlation in the reduction of ROS and NADPH oxidase activity. Specifically, for the heparan sulfateglycomimetic $\alpha-\mathbf{4}$ (Table 2, entry $\mathbf{1}$ ), the concentration of NO increase by $+110 \%$ compared to the control. However, the increased phosphorylation of eNOS is comparable to the other compounds tested, with the exception of $R-\mathbf{1 0}$, which is shown to increase eNOS phosphorylation significantly greater than all the other compounds tested $(+613 \%$, Table 2 , entry 4$)$. All the remaining compounds demonstrated similar biological activity.

\section{ADMET data on hit glycomimetics}

The triaged glycomimetics have been independently analysed for their ADMET properties (Table 3). All showed high kinetic solubility, no cytotoxic effect in Hep G2 cells, long half-life in mouse liver microsomes (MLMs) and rat liver microsomes (RLMs) and due to the compound stability, low levels of intrinsic clearance $\left(\mathrm{CL}_{\mathrm{int}}\right)$. Furthermore, no inhibition of the cardiac ion channel, hERG was observed. As expected, Caco-2 cell permeability levels were low or not detected due to the highly polar nature of $\beta-\mathbf{5}$ and $R \mathbf{- 1 0}$ lending support to the cell receptor interaction proposed. A potential concern is CYP-mediated metabolic oxidation due to the para-arrangement of the phenolic groups in the 2,5-substituted glycomimetics, potentially leading to quinone-type reactive intermediates or loss of the sulfate groups, was not observed in the examples tested.

\section{Conclusions}

We have identified a promising series of persulfated and non-sulfated small molecule heparan sulfate-glycomimetics that elicit a protective effect in our simulated lipid-induced endothelial dysfunction model. All examples tested demonstrate an increase in NO production after oxidative stress through the eNOS phosphorylation biomarker, and

Table 2 Biological data for eNOS and ROS levels. All data are averaged \% of increase (+) or decrease (-) compared to control (FFA induced oxidatively stressed endothelial cells) $(n=3)$

\begin{tabular}{llllll}
\hline Entry & Compound number & NO production & eNOS phosphorylation & ROS production & NADPH oxidase activity \\
\hline 1 & $\alpha-\mathbf{4}$ & +110 & +342 & -28 & -29 \\
2 & $\beta-5$ & +62 & +318 & -29 & -31 \\
3 & $S-10$ & +63 & +397 & -39 & -27 \\
4 & $R-10$ & +52 & +613 & -23 & -31 \\
5 & $\alpha-3$ & +41 & +312 & -23 & -21 \\
6 & $\beta-3$ & +52 & +294 & -19 & -27 \\
7 & $\alpha-2$ & +46 & +286 & -36 & -26
\end{tabular}


Table 3 Physicochemical and ADMET properties of representative glycomimetics. $\mathrm{NR}=$ no response, $\mathrm{ND}=$ not determined, $\mathrm{MEC}=$ minimum effective concentration that significantly crosses vehicle control threshold, $\mathrm{AC}_{50}=$ the concentration at which $50 \%$ maximum effect is observed for each cell health parameter. Kinetic solubility measured with a turbidimetric assay (controls: nicardipine and pyrene). MTT (cytotoxicity) study using HepG2 cells (Cyprotex, Macclesfield, UK; controls: carbonyl cyanide 3-chlorophenylhydrazone and chlorpromazine). MLM assay (controls: diphenhydramine and diazepam). hERG assay (controls: quinidine and dimethylsulfoxide). Caco-2 assay (ATCC, Virginia, USA; controls: atenolol, propranolol, and talinolol)

\begin{tabular}{|c|c|c|c|c|}
\hline Compounds & & & & \\
\hline Parameters & $\alpha-4$ & $\beta-5$ & $R-10$ & $S-10$ \\
\hline Molecular weight (Da) & 723.87 & 731.83 & 619.95 & $\overline{619.95}$ \\
\hline $\operatorname{tPSA}\left(\AA^{2}\right)$ & 299 & 310 & 235 & 235 \\
\hline $\operatorname{clog} P$ & -1.44 & -1.96 & -0.13 & -0.13 \\
\hline Number of HBAs & 20 & 20 & 16 & 16 \\
\hline Number of HBDs & 4 & 5 & 3 & 3 \\
\hline Chemical stability & Yes & Yes & Yes & Yes \\
\hline
\end{tabular}

Assay results

\begin{tabular}{|c|c|c|c|c|}
\hline Kinetic solubility $(\mu \mathrm{M})$ & $>100$ & $>100$ & $>100$ & $>100$ \\
\hline $\begin{array}{l}\text { HUVEC cell viability } \\
(1-500 \mu \mathrm{M})\end{array}$ & NR & NR & NR & NR \\
\hline MTT (MEC, $\mu \mathrm{M})$ & NR & NR & NR & NR \\
\hline $\operatorname{MTT}\left(\mathrm{AC}_{50}, \mu \mathrm{M}\right)$ & NR & NR & NR & NR \\
\hline $\operatorname{MLM} t_{1 / 2}(\min )$ & 1840 & 482 & 3450 & 4160 \\
\hline $\begin{array}{l}\text { Mouse } \mathrm{CL}_{\text {int }} \\
\left(\mu \mathrm{L} \min ^{-1} \mathrm{mg}^{-1}\right)\end{array}$ & 0.755 & 2.88 & 0.402 & 0.333 \\
\hline $\operatorname{RLM} t_{1 / 2}(\min )$ & 145 & 2140 & 338 & 109 \\
\hline $\begin{array}{l}\text { Rat } \mathrm{CL}_{\text {int }} \\
\left(\mu \mathrm{Lin}^{-1} \mathrm{mg}^{-1}\right)\end{array}$ & 9.56 & 0.649 & 4.11 & 12.8 \\
\hline hERG & ND & $>25 \mu \mathrm{M}$ & $>25 \mu \mathrm{M}$ & ND \\
\hline $\begin{array}{l}\text { Caco-2 } \\
\left(\mathrm{B}_{2} \mathrm{~A} P_{\text {app }} 10^{-6} \mathrm{~cm} \mathrm{~s}^{-1}\right)\end{array}$ & ND & Not detected & Not detected & ND \\
\hline $\begin{array}{l}\text { Caco-2 } \\
\left(\mathrm{A}_{2} \mathrm{~B} P_{\text {app }} 10^{-6} \mathrm{~cm} \mathrm{~s}^{-1}\right)\end{array}$ & ND & Not detected & 0.931 & ND \\
\hline
\end{tabular}

significant decrease in reactive oxygen species (ROS) production through NADPH oxidase activity knock-down. Significantly higher protective effects were observed in the sulfated glycomimetic series compared to the desulfated precursors.

Therefore, coupled with these heparan sulfateglycomimetics encouraging ADMET profiles (chemically stable, non-toxic against HUVECs, MTT and hERG; excellent water solubility; and long $t_{1 / 2}$ ), modelled interaction profile through molecular docking to HGF and simulated dynamics studies demonstrate these heparan sulfate-glycomimetics as a new source of bespoke mimics for ongoing hit-to-lead studies targeting inflammation and cardiovascular disease.

\section{Experimental}

Selected compound characterisation

All general procedures can be located in the ESI. $\dagger$

$(\alpha-2) \quad$ methyl 5-((R)-2,3-dihydroxypropoxy $)-2-((S)-2,3-$ dihydroxypropoxy)benzoate

Adapted from general procedure $D^{26}$ using stock solutions. I ( $2 \mathrm{~mL}, 3.0 \mathrm{mmol}), \mathbf{I I}(2 \mathrm{~mL}, 3.0 \mathrm{mmol}), \mathbf{I I I}(1.0 \mathrm{~mL}, 2.0 \mu \mathrm{mol})$ and IV (5.0 mL, $20.0 \mu \mathrm{mol}) .^{27}$ Methyl 2,5-bis(allyloxy)benzoate (1) $(158 \mathrm{mg}, 0.50 \mathrm{mmol})$ was added and the reaction mixture was stirred at $0{ }^{\circ} \mathrm{C}$ for $6 \mathrm{~h}$ with monitoring (EtOH/EtOAc $1: 4$, $\left.R_{\mathrm{f}}=0.20\right)$. The solvent was removed under reduced pressure and the crude mixture was directly purified by chromatography $\left(\mathrm{SiO}_{2}, \mathrm{EtOAc} /\right.$ hexane $\left.1: 4\right)$ to afford the title compound as a clear oil (156 mg, 99\%). $[\alpha]_{\mathrm{D}}{ }^{25}-13.15$ (c. 1.0, MeOH, 36:6:4:54 e.r/d.r (2R,5R; 2S,5S; $2 R, 5 S ; 2 S, 5 R))$; IR $v_{\max } \mathrm{cm}^{-1} 3268 \mathrm{w}, 2939 \mathrm{w}, 2890 \mathrm{w}, 1699 \mathrm{~s}(\mathrm{C}=\mathrm{O}), 1601 \mathrm{w}$, $1499 \mathrm{~s}, 1435 \mathrm{w} ;{ }^{1} \mathbf{H}-\mathrm{NMR}\left(400 \mathrm{MHz},\left(\mathrm{CD}_{3}\right)_{2} \mathrm{SO}\right) \delta_{\mathrm{H}} 7.18(\mathrm{~d}, J=$ $2.7 \mathrm{~Hz}, 1 \mathrm{H}, \mathrm{C} 6-\underline{\mathrm{H}}), 7.15-7.04$ (m, 2H, C3- $\underline{\mathrm{H}} \& \mathrm{C} 4-\underline{\mathrm{H}}), 4.94$ (d, $J=5.0 \mathrm{~Hz}, 1 \mathrm{H}, \mathrm{CH}-\mathrm{O} \underline{\mathrm{H}}), 4.84(\mathrm{~d}, J=5.0 \mathrm{~Hz}, 1 \mathrm{H}, \mathrm{CH}-\mathrm{OH})$, $4.66\left(\mathrm{t}, J=5.7 \mathrm{~Hz}, 1 \mathrm{H}, \mathrm{CH}_{2}-\mathrm{OH}\right), 4.59\left(\mathrm{t}, J=5.7 \mathrm{~Hz}, 1 \mathrm{H}, \mathrm{CH}_{2}-\right.$ $\mathrm{OH}), 4.01-3.85(\mathrm{~m}, 3 \mathrm{H}), 3.86-3.69(\mathrm{~m}, 6 \mathrm{H}, \mathrm{Me}), 3.55-3.35(\mathrm{~m}$, $4 \mathrm{H}) ;{ }^{13} \mathrm{C}-\mathrm{NMR}\left(101 \mathrm{MHz},\left(\mathrm{CD}_{3}\right)_{2} \mathrm{SO}\right) \delta_{\mathrm{C}} 166.0\left(\mathrm{CO}_{2} \mathrm{Me}\right), 152.2$ (C5), 152.0 (C2), 121.0 (C1), 119.8 (C3/C4), 115.94 (C3/C4), 115.89 (C6), $71.3\left(\mathrm{ArO}-\mathrm{CH}_{2}\right), 70.3\left(\mathrm{ArO}-\mathrm{CH}_{2}\right), 69.9(2 \mathrm{C}, \underline{\mathrm{C}} \mathrm{H}-$ $\mathrm{OH}), 62.72\left(\mathrm{C}_{2}-\mathrm{OH}\right), 62.66\left(\mathrm{C}_{2}-\mathrm{OH}\right), 52.0(\mathrm{Me}) ; \mathbf{L R M S ~} \mathrm{m} / \mathrm{z}$ $\left(\mathrm{ESI}^{+}\right) 339.12\left(100 \%\right.$, $\left.[\mathrm{M}+\mathrm{Na}]^{+}\right)$; HRMS $\mathrm{m} / z(\mathrm{ESI}+) \mathrm{C}_{14} \mathrm{H}_{20} \mathrm{O}_{8^{-}}$ Na requires: 339.1056 , found: $339.1057\left([\mathrm{M}+\mathrm{Na}]^{+}\right)$.

$(\alpha-3) \quad$ sodium $\quad 5-((R)-2,3-d i h y d r o x y p r o p o x y)-2-(( \pm)-2,3-$ dihydroxypropoxy)benzoate. A solution of methyl $5-((R)-2,3-$ dihydroxypropoxy)-2-(( \pm -2,3-dihydroxypropoxy)benzoate $(\alpha-2)$ $(100 \mathrm{mg}, 0.32 \mathrm{mmol})$ in $\mathrm{MeOH}(10 \mathrm{~mL})$ was charged with $\mathrm{NaOH}(13 \mathrm{mg}, 0.32 \mathrm{mmol})$. The reaction mixture was heated under reflux for $2 \mathrm{~h}$, then cooled to room temperature. The solvent was removed under reduced pressure to afford the title compound as a hygroscopic white solid (103 mg, 99\%). $[\alpha]_{\mathrm{D}}{ }^{25}-10.48$ (c. 1.0, MeOH, 36: $6: 4$ : 54 e.r/d.r (RR,SS,RS,SR)); IR $v_{\max } \mathrm{cm}^{-1} 3246 \mathrm{br} \mathrm{s}(\mathrm{O}-\mathrm{H}), 2934 \mathrm{w}, 2877 \mathrm{w}, 1559 \mathrm{~s}(\mathrm{C}=\mathrm{O})$, $1491 \mathrm{~s}, 1455 \mathrm{w}, 1420 \mathrm{~s}, 1374 \mathrm{~s} ;{ }^{1} \mathrm{H}-\mathrm{NMR}\left(400 \mathrm{MHz}, \mathrm{CD}_{3} \mathrm{OD}\right)$ $\delta_{\mathrm{H}} 7.36(\mathrm{~d}, J=3.1 \mathrm{~Hz}, 1 \mathrm{H}, \mathrm{C} 6-\underline{\mathrm{H}}), 7.15(\mathrm{dd}, J=9.0,3.1 \mathrm{~Hz}$, 1H, C4- $\underline{\mathrm{H}}$ ), 7.12-7.05 (m, 2H, C6- $\underline{\mathrm{H}} \& \mathrm{C} 3-\underline{\mathrm{H}}), 6.93$ (d, $J=9.0$ $\mathrm{Hz}, 1 \mathrm{H}, \mathrm{C} 3-\underline{\mathrm{H}}), 6.87$ (dd, $J=9.0,3.0 \mathrm{~Hz}, 1 \mathrm{H}, \mathrm{C} 4-\underline{\mathrm{H}}), 4.16-3.86$ (m, $2 \times 6 \mathrm{H}), 3.79-3.57(\mathrm{~m}, 2 \times 4 \mathrm{H}) ;{ }^{13} \mathbf{C}-\mathbf{N M R}\left(101 \mathrm{MHz}, \mathrm{CD}_{3^{-}}\right.$ OD) $\delta_{\mathrm{C}} 175.9,154.4,154.34,154.25,151.7,132.8,122.0,121.5$, $117.8,117.2,116.7,116.6,116.2,73.2,72.8,71.9,71.8$ (2C), 71.6, 71.1, 70.9, 64.3, 64.2, 64.1, 63.9; LRMS $\mathrm{m} / \mathrm{z}$ (ESI+) 325.09 $\left(30 \%,[\mathrm{M}+\mathrm{H}]^{+}\right)$; HRMS $\mathrm{m} / \mathrm{z}(\mathrm{ESI}+) \mathrm{C}_{13} \mathrm{H}_{18} \mathrm{NaO}_{8}$ requires: 325.0894, found: $325.0895\left([\mathrm{M}+\mathrm{H}]^{+}\right)$.

( $\beta-3)$ sodium 5-((S)-2,3-dihydroxypropoxy)-2-(( \pm$)-2,3-$ dihydroxypropoxy)benzoate. A solution of methyl 5-((S)-2,3dihydroxypropoxy)-2-(( \pm -2,2,-dihydroxypropoxy)benzoate ( $\beta-2)$ $(100 \mathrm{mg}, 0.32 \mathrm{mmol})$ in $\mathrm{MeOH}(10 \mathrm{~mL})$ was charged with $\mathrm{NaOH}(13 \mathrm{mg}, 0.32 \mathrm{mmol})$. The reaction mixture was heated under reflux for $2 \mathrm{~h}$, then cooled to room temperature. The solvent was removed under reduced pressure to afford the title compound as a hygroscopic white solid (103 mg, 99\%). $[\alpha]_{\mathrm{D}}{ }^{25}-8.31$ (c. 1.0, MeOH, 1:51:46:2 e.r/d.r (RR,SS,RS,SR)); IR $v_{\max } \mathrm{cm}^{-1} 3249$ br s $(\mathrm{O}-\mathrm{H}), 2934 \mathrm{w}, 2879 \mathrm{w}, 1559 \mathrm{~s}(\mathrm{C}=\mathrm{O})$, $1491 \mathrm{~s}, 1455 \mathrm{w}, 1420 \mathrm{~s}, 1374 \mathrm{~s} ;{ }^{1} \mathrm{H}-\mathrm{NMR}\left(400 \mathrm{MHz}, \mathrm{CD}_{3} \mathrm{OD}\right)$ $\delta_{\mathrm{H}} 7.36(\mathrm{~d}, J=3.1 \mathrm{~Hz}), 7.15(\mathrm{dd}, J=8.9,3.1 \mathrm{~Hz}), 7.12-7.07(\mathrm{~m}$, $1 \mathrm{H}, \mathrm{C} 6-\underline{\mathrm{H}}), 6.93$ (d, $J=8.9 \mathrm{~Hz}, 1 \mathrm{H}, \mathrm{C} 3-\underline{\mathrm{H}}), 6.87$ (dd, $J=8.9$, $3.1 \mathrm{~Hz}, 1 \mathrm{H}, \mathrm{C} 4-\underline{\mathrm{H}}), 4.20-3.84(\mathrm{~m}, 2 \times 6 \mathrm{H}), 3.78-3.55(\mathrm{~m}, 2 \times$ $4 \mathrm{H}) ;{ }^{13} \mathrm{C}-\mathrm{NMR}\left(101 \mathrm{MHz}, \mathrm{CD}_{3} \mathrm{OD}\right) \delta_{\mathrm{C}} 176.4\left(\mathrm{CO}_{2} \mathrm{Me}\right), 154.9$, 154.9, 154.8, 152.3, 133.3, 122.0, 118.4, 117.7, 117.3, 117.12 
(2C), 116.8, 116.7, 73.7, 73.3, 72.4, 72.3, 72.1, 71.6, 71.4, 64.8, 64.7, 64.6, 64.5; LRMS $m / z$ (ESI+) $325.09\left(30 \%,[\mathrm{M}+\mathrm{H}]^{+}\right)$; HRMS $m / z$ (ESI+) $\mathrm{C}_{13} \mathrm{H}_{18} \mathrm{NaO}_{8}$ requires: 325.0894, found: $325.0890\left([\mathrm{M}+\mathrm{H}]^{+}\right)$.

$(\alpha-4) \quad$ sodium 3-(4-((S)-2,3-bis(sulfonatooxy)propoxy)-2(methoxycarbonyl)phenoxy)propane-1,2-diyl bis(sulfate)

Adapted from general procedure $\boldsymbol{E}^{28}$. A $25 \mathrm{~mL}$ Schlenk tube was charged with $\alpha-5$ (81 mg, $0.25 \mathrm{mmol}$ ) and $\mathrm{Bu}_{3} \mathrm{~N} \cdot \mathrm{SO}_{3}(530$ $\mathrm{mg}, 2.00 \mathrm{mmol})$ under $\mathrm{Ar}$ and $\mathrm{MeCN}$ was added $(0.5 \mathrm{~mL})$. The flask was heated at $80{ }^{\circ} \mathrm{C}$ for $12 \mathrm{~h}$ with monitoring (TLC). The flask was cooled to room temperature and the solvent removed under reduced pressure to give a clear viscous oil. The crude oil was dissolved in ${ }^{\mathrm{i}} \mathrm{PrOH}(5 \mathrm{~mL})$ and transferred to a flask containing ${ }^{t}$ BuOMe $(35 \mathrm{~mL})$. With vigorous stirring a solution of $\mathrm{NEH}(5.0 \mathrm{~mL}, 1.0 \mathrm{M})$ in ${ }^{t}$ $\mathrm{BuOMe} /{ }^{\mathrm{i}} \mathrm{PrOH}(1: 7)$ was added dropwise over $10 \mathrm{~min}$. The precipitate that formed was collected by filtration, washed with ${ }^{\mathrm{i}} \mathrm{PrOH}(2 \times 10 \mathrm{~mL})$ and dried under vacuum. Recrystallization from $\mathrm{H}_{2} \mathrm{O} /{ }^{\mathrm{i}} \mathrm{PrOH}$ afforded the title compound as a white solid (160 mg, 88\%). $[\alpha]_{\mathrm{D}}{ }^{25}-3.35$ (c. 1.0, $\mathrm{H}_{2} \mathrm{O}, 36: 6: 4: 54$ e.r/d.r $\left.(S S, R R, S R, R S)\right)$; M.P $198-200{ }^{\circ} \mathrm{C}$ (dec.); IR $v_{\max } \mathrm{cm}^{-1} 2988 \mathrm{w}, 2164 \mathrm{w}, 1711 \mathrm{w}(\mathrm{C}=\mathrm{O}), 1500 \mathrm{w}$, $1443 \mathrm{w}, 1221 \mathrm{~s}(\mathrm{~S}=\mathrm{O}), 1131 \mathrm{~s}(\mathrm{~S}=\mathrm{O}) ;{ }^{1} \mathbf{H}-\mathbf{N M R}(400 \mathrm{MHz}$, $\left.\mathrm{D}_{2} \mathrm{O}\right) \delta_{\mathrm{H}} 7.45$ (d, $\left.J=3.1 \mathrm{~Hz}, 1 \mathrm{H}, \mathrm{C} 6-\underline{\mathrm{H}}\right), 7.27$ (dd, $J=9.1,3.1$ $\mathrm{Hz}, 1 \mathrm{H}, \mathrm{C} 4-\underline{\mathrm{H}}$ ), 7.19 (d, $J=9.1 \mathrm{~Hz}, 1 \mathrm{H}, \mathrm{C} 3-\underline{\mathrm{H}}), 4.87$ (td, $J=$ 4.8, $\left.1.8 \mathrm{~Hz}, 2 \mathrm{H}, \mathrm{C} \underline{\mathrm{H}}-\mathrm{OSO}_{3} \mathrm{Na}\right), 4.45-4.25$ (m, 8H, $\mathrm{Ar}-\mathrm{OCH}_{2}$, $\mathrm{CH}_{2}-\mathrm{OSO}_{3} \mathrm{Na}$ ), 3.93 (s, 3H, Me); ${ }^{13} \mathrm{C}-\mathrm{NMR}$ (101 MHz, $\left.\mathrm{D}_{2} \mathrm{O}\right) \delta$ 168.5 ( $\mathrm{CO}_{2} \mathrm{Me}$ ), 152.2 (C2), 152.1 (C5), 121.4 (C4), 120.8 (C1), 117.4 (C6), 116.9 (C3), 75.03 ( $\left.\underline{\mathrm{C}} \mathrm{H}-\mathrm{OSO}_{3} \mathrm{Na}\right), 74.98\left(\underline{\mathrm{C}} \mathrm{H}-\mathrm{OSO}_{3}-\right.$ $\mathrm{Na}), 68.2\left(\mathrm{O}-\underline{\mathrm{CH}}_{2}\right), 67.3\left(\mathrm{O}-\underline{\mathrm{C}} \mathrm{H}_{2}\right), 66.44\left(\underline{\mathrm{CH}}_{2}-\mathrm{OSO}_{3} \mathrm{Na}\right), 66.41$ $\left(\underline{\mathrm{CH}}_{2}-\mathrm{OSO}_{3} \mathrm{Na}\right), 52.8(\mathrm{Me})$; LRMS $\mathrm{m} / \mathrm{z}(\mathrm{ESI}+) 746.86$ (20\%, [M + $\left.\mathrm{Na}]^{+}\right)$; HRMS $\mathrm{m} / \mathrm{z}(\mathrm{ESI}+) \mathrm{C}_{14} \mathrm{H}_{16} \mathrm{Na}_{5} \mathrm{O}_{20} \mathrm{~S}_{4}$ requires: 746.8601, found: $746.8591\left([\mathrm{M}+\mathrm{Na}]^{+}\right)$.

( $\beta$-5) Sodium 5- $((R)-2,3-b i s($ sulfonatooxy)propoxy)-2-(2,3bis(sulfonatooxy)propoxy)benzoate

Adapted from general procedure $\boldsymbol{E}^{28}$. A $25 \mathrm{~mL}$ Schlenk tube was charged with $\beta-3$ (100 mg, $0.32 \mathrm{mmol}$ ) and $\mathrm{Bu}_{3} \mathrm{~N} \cdot \mathrm{SO}_{3}$ (678 $\mathrm{mg}, 2.56 \mathrm{mmol})$ under $\operatorname{Ar}_{(\mathrm{g})}$ and $\mathrm{MeCN}$ was added (0.6 $\mathrm{mL})$. The flask was heated at $80{ }^{\circ} \mathrm{C}$ for $12 \mathrm{~h}$ and with monitoring (TLC). The flask was cooled to room temperature and the solvent removed under reduced pressure to give a clear viscous oil. The crude oil was dissolved in ${ }^{\mathrm{i}} \mathrm{PrOH}(5 \mathrm{~mL})$ and transferred to a flask containing ${ }^{t}$ BuOMe $(35 \mathrm{~mL})$. With vigorous stirring a solution of $\mathrm{NEH}(5.0 \mathrm{~mL}, 1.0 \mathrm{M})$ in $^{t}$ $\mathrm{BuOMe} /{ }^{\mathrm{i}} \mathrm{PrOH}(1: 7)$ was added dropwise over $10 \mathrm{~min}$. The precipitate that formed was collected by filtration, washed with ${ }^{\mathrm{i}} \mathrm{PrOH}(2 \times 10 \mathrm{~mL})$ and dried under vacuum. Recrystallization from $\mathrm{H}_{2} \mathrm{O} /{ }^{\mathrm{i}} \mathrm{PrOH}$ afforded the title compound as a white solid (200 mg, 86\%). $[\alpha]_{\mathrm{D}}{ }^{25}-1.66$ (c. 1.0, $\mathrm{H}_{2} \mathrm{O}, 1: 51: 46: 2$ e.r/d.r $\left.(S S, R R, S R, R S)\right)$; M.P $200-202{ }^{\circ} \mathrm{C}$ (dec.); IR $v_{\max } \mathrm{cm}^{-1} 2988 \mathrm{w}, 1712 \mathrm{w}(\mathrm{C}=\mathrm{O}), 1499 \mathrm{w}, 1435 \mathrm{w}$, $1100 \mathrm{~s}(\mathrm{~S}=\mathrm{O}) ;{ }^{1} \mathrm{H}-\mathrm{NMR}\left(400 \mathrm{MHz}, \mathrm{D}_{2} \mathrm{O}\right) \delta$ 7.47-6.94 (m, 3H), 5.00-4.73 (m, 2H), 4.46-3.99 (m, 8H); ${ }^{13} \mathrm{C}-\mathrm{NMR}(101 \mathrm{MHz}$,

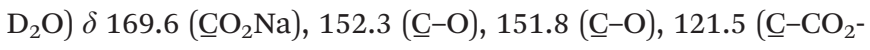
$\mathrm{Na}), 120.7$ ( $\underline{\mathrm{C}}-\mathrm{H}), 117.4(\underline{\mathrm{C}}-\mathrm{H}), 116.2(\underline{\mathrm{C}}-\mathrm{H}), 75.0(\underline{\mathrm{C}}-\mathrm{H}), 74.9$ $(\underline{\mathrm{C}}-\mathrm{H}), 68.3\left(\underline{\mathrm{C}}-\mathrm{H}_{2}\right), 67.3\left(\underline{\mathrm{C}}-\mathrm{H}_{2}\right), 66.6\left(\underline{\mathrm{C}}-\mathrm{H}_{2}\right), 66.4\left(\underline{\mathrm{C}}-\mathrm{H}_{2}\right)$;
LRMS $\mathrm{m} / \mathrm{z}(\mathrm{ESI}+) 732.84\left(10 \%,[\mathrm{M}+\mathrm{H}]^{+}\right) ;$HRMS $\mathrm{m} / \mathrm{z}(\mathrm{ESI}+)$ $\mathrm{C}_{13} \mathrm{H}_{14} \mathrm{Na}_{5} \mathrm{O}_{20} \mathrm{~S}_{4}$ requires: 732.8444 , found: $732.8439([\mathrm{M}+$ $\left.\mathrm{H}]^{+}\right)$.

(R-10) Sodium $\quad(R)-3-(3-(m e t h o x y c a r b o n y l)-4-(4-$ (sulfonatooxy)butoxy)phenoxy)propane-1,2-diyl bis(sulfate)

Adapted from general procedure $\boldsymbol{E}^{28}$. A $25 \mathrm{~mL}$ Schlenk tube was charged with $S-9$ (135 $\mathrm{mg}, 0.45 \mathrm{mmol})$ and $\mathrm{Bu}_{3} \mathrm{~N} \cdot \mathrm{SO}_{3}$ (722 mg, $2.72 \mathrm{mmol}$ ) under $\mathrm{Ar}_{(\mathrm{g})}$ and $\mathrm{MeCN}$ was added (1.5 $\mathrm{mL}$ ). The flask was heated at $80^{\circ} \mathrm{C}$ for $12 \mathrm{~h}$ with monitoring (TLC). The flask was cooled to room temperature and the solvent removed under reduced pressure to give a clear viscous oil. The crude oil was dissolved in ${ }^{\mathrm{i}} \mathrm{PrOH}(5 \mathrm{~mL})$ and transferred to a flask containing ${ }^{t} \mathrm{BuOMe}(35 \mathrm{~mL})$. With vigorous stirring a solution of $\mathrm{NEH}(5.0 \mathrm{~mL}, 1.0 \mathrm{M})$ in ${ }^{t}$ $\mathrm{BuOMe} /{ }^{\mathrm{i}} \mathrm{PrOH}(1: 7)$ was added dropwise over $10 \mathrm{~min}$. The precipitate that formed was collected by filtration, washed with ${ }^{\mathrm{i}} \mathrm{PrOH}(2 \times 10 \mathrm{~mL})$ and dried under vacuum. Recrystallization from $\mathrm{H}_{2} \mathrm{O} /{ }^{\mathrm{i}} \mathrm{PrOH}$ afforded the title compound as a white solid (260 mg, 94\%). $[\alpha]_{\mathrm{D}}{ }^{25}-3.11$ (c. 1.0, $\mathrm{CHCl}_{3}$ ); M.P $207-210{ }^{\circ} \mathrm{C}$ (dec.); IR $v_{\max } \mathrm{cm}^{-1} 2972 \mathrm{w}, 2166$ w, $1703 \mathrm{w}(\mathrm{C}=\mathrm{O}), 1500 \mathrm{w}, 1441 \mathrm{w}, 1103 \mathrm{~s}(\mathrm{~S}=\mathrm{O}) ;{ }^{1} \mathbf{H}-\mathbf{N M R}$ $\left(400 \mathrm{MHz}, \mathrm{D}_{2} \mathrm{O}\right) \delta_{\mathrm{H}} 7.42(\mathrm{~d}, J=3.2 \mathrm{~Hz}, 1 \mathrm{H}, \mathrm{C} 6-\underline{\mathrm{H}}), 7.25$ (dd, $J$ $=9.2,3.2 \mathrm{~Hz}, 1 \mathrm{H}, \mathrm{C} 4-\underline{\mathrm{H}}), 7.14(\mathrm{~d}, J=9.2 \mathrm{~Hz}, 1 \mathrm{H}, \mathrm{C} 3-\underline{\mathrm{H}}), 4.86$ (p, $\left.J=4.8 \mathrm{~Hz}, 1 \mathrm{H}, \mathrm{C} \underline{\mathrm{H}}-\mathrm{OSO}_{3} \mathrm{Na}\right), 4.42-4.29(\mathrm{~m}, 3 \mathrm{H}), 4.26(\mathrm{dd}, J$ = 11.0, $5.2 \mathrm{~Hz}, 1 \mathrm{H}), 4.16-4.05(\mathrm{~m}, 4 \mathrm{H}), 3.90(\mathrm{~s}, 3 \mathrm{H}, \mathrm{Me}), 1.86$ $\left(\mathrm{m}, 4 \mathrm{H},\left(\mathrm{C}_{2}\right)_{2}\right) ;{ }^{13} \mathrm{C}-\mathrm{NMR}\left(101 \mathrm{MHz}, \mathrm{D}_{2} \mathrm{O}\right) \delta_{\mathrm{C}} 168.4\left(\mathrm{C}_{2} \mathrm{Me}\right)$, 152.6 (C2), 151.7 (C5), 121.6 (C4), 120.1 (C1), 117.3 (C6), 116.4 (C3), $75.0\left(\underline{\mathrm{CH}}-\mathrm{OSO}_{3} \mathrm{Na}\right), 69.7,69.0,67.3,66.4,52.7$ (Me), $25.2\left(\left(\underline{\mathrm{CH}}_{2}\right)_{2}\right), 24.9\left(\left(\underline{\mathrm{CH}}_{2}\right)_{2}\right)$; LRMS $\mathrm{m} / \mathrm{z}$ (ESI+) 642.94 $\left(40 \%,[\mathrm{M}+\mathrm{Na}]^{+}\right)$; HRMS $\mathrm{m} / z(\mathrm{ESI}+) \mathrm{C}_{15} \mathrm{H}_{19} \mathrm{Na}_{4} \mathrm{O}_{16} \mathrm{~S}_{3}$ requires: 642.9421, found: $642.9426\left([\mathrm{M}+\mathrm{Na}]^{+}\right)$.

(S-10) Sodium $\quad(S)-3-(3-(m e t h o x y c a r b o n y l)-4-(4-$ (sulfonatooxy)butoxy)phenoxy)propane-1,2-diyl bis(sulfate)

Adapted from general procedure $\boldsymbol{E}^{28}$. A $25 \mathrm{~mL}$ Schlenk tube was charged with $R-\mathbf{9}(215 \mathrm{mg}, 0.72 \mathrm{mmol})$ and $\mathrm{Bu}_{3} \mathrm{~N} \cdot \mathrm{SO}_{3}$ (1.145 g, $2.56 \mathrm{mmol})$ under $\operatorname{Ar}_{(\mathrm{g})}$ and $\mathrm{MeCN}$ was added (1.5 $\mathrm{mL}$ ). The flask was heated at $80^{\circ} \mathrm{C}$ for $12 \mathrm{~h}$ with monitoring (TLC). The flask was cooled to room temperature and the solvent removed under reduced pressure to give a clear viscous oil. The crude oil was dissolved in ${ }^{\mathrm{i}} \mathrm{PrOH}(5 \mathrm{~mL})$ and transferred to a flask containing ${ }^{t} \mathrm{BuOMe}(35 \mathrm{~mL})$. With vigorous stirring a solution of $\mathrm{NEH}(5.0 \mathrm{~mL}, 1.0 \mathrm{M})$ in ${ }^{t}$ $\mathrm{BuOMe} /{ }^{\mathrm{i}} \mathrm{PrOH}$ (1:7) was added dropwise over $10 \mathrm{~min}$. The precipitate that formed was collected by filtration, washed with ${ }^{\mathrm{i}} \mathrm{PrOH}(2 \times 10 \mathrm{~mL})$ and dried under vacuum. Recrystallization from $\mathrm{H}_{2} \mathrm{O} /{ }^{\mathrm{i}} \mathrm{PrOH}$ afforded the title compound as a white solid (430 mg, 97\%). $[\alpha]_{\mathrm{D}}{ }^{25}+3.01$ (c. 1.0, $\mathrm{H}_{2} \mathrm{O}$ ); M.P $207-210{ }^{\circ} \mathrm{C}$ (dec.); IR $v_{\max } \mathrm{cm}^{-1} 2971 \mathrm{w}, 2164$ w, $1710 \mathrm{w}(\mathrm{C}=\mathrm{O}), 1500 \mathrm{w}, 1441 \mathrm{w}, 1103 \mathrm{~s}(\mathrm{~S}=\mathrm{O}) ;{ }^{1} \mathbf{H}-\mathbf{N M R}$ (400 MHz, D $2 \mathrm{O}) \delta_{\mathrm{H}} 7.43(\mathrm{~d}, J=3.2 \mathrm{~Hz}, 1 \mathrm{H}, \mathrm{C} 6-\underline{\mathrm{H}}$ ), 7.25 (dd, $J$ $=9.2,3.2 \mathrm{~Hz}, 1 \mathrm{H}, \mathrm{C} 4-\underline{\mathrm{H}}), 7.14(\mathrm{~d}, J=9.2 \mathrm{~Hz}, 1 \mathrm{H}, \mathrm{C} 3-\underline{\mathrm{H}}), 4.87$ $\left(\mathrm{p}, J=4.7 \mathrm{~Hz}, 1 \mathrm{H}, \mathrm{C} \underline{\mathrm{H}}-\mathrm{OSO}_{3} \mathrm{Na}\right), 4.44-4.29(\mathrm{~m}, 3 \mathrm{H}), 4.26(\mathrm{dd}, J$ $=11.0,5.2 \mathrm{~Hz}, 1 \mathrm{H}), 4.12(\mathrm{~m}, 4 \mathrm{H}), 3.90$ (s, 3H, Me), 1.94-1.79 $\left(\mathrm{m}, 4 \mathrm{H},\left(\mathrm{C}_{2}\right)_{2}\right) ;{ }^{13} \mathrm{C}-\mathrm{NMR}\left(101 \mathrm{MHz}, \mathrm{D}_{2} \mathrm{O}\right) \delta_{\mathrm{C}} 168.4\left(\mathrm{C}_{2} \mathrm{Me}\right)$, 152.6 (C2), 151.7 (C5), 121.6 (C4), 120.1 (C1), 117.3 (C6), 116.4 (C3), $75.0\left(\underline{\mathrm{C} H}-\mathrm{OSO}_{3} \mathrm{Na}\right), 69.7,69.0,67.4,66.4,52.7$ 
(Me), $25.2\left(\left(\underline{\mathrm{CH}}_{2}\right)_{2}\right), 24.9\left(\left(\mathrm{CH}_{2}\right)_{2}\right)$; LRMS $\mathrm{m} / \mathrm{z}$ (ESI+) 642.94 $\left(50 \%,[\mathrm{M}+\mathrm{Na}]^{+}\right)$; HRMS $\mathrm{m} / z(\mathrm{ESI}+) \mathrm{C}_{15} \mathrm{H}_{19} \mathrm{Na}_{4} \mathrm{O}_{16} \mathrm{~S}_{3}$ requires: 642.9421, found: $642.9417\left([\mathrm{M}+\mathrm{Na}]^{+}\right)$.

\section{Conflicts of interest}

A. M. J. and M. Y. A. have a commercial interest in glycomimetics (UK Patent Application No. 1515850.4 and PCT Patent Application No. PCT/GB2016/052764).

\section{Acknowledgements}

This study was financed in part by the Coordenação de Aperfeiçoamento de Pessoal de Nível Superior-Brasil (CAPES)Finance Code 001 in the form of research scholarships for A. P. R. P. and G. Z. D. M. G. thanks the University of Birmingham for a Ph.D scholarship. S. A. S. and A. M. J. thank the Wellcome Trust for the award of a Biomedical Vacation Scholarship (202151/Z/16/Z). A. M. M. thanks the Alexander Von Humboldt Foundation for funding his postdoctoral fellowship (ID 1158232) and the International Atherosclerosis Society (IAS; USA) for a travel grant. A. M. J., M. Y. A. and F. L. W. thank the Healthcare Science Research Centre for a Support of Excellence Award and Cyprotex (Macclesfield, UK) for ADMET studies. The authors thank the Centre for Chemical and Materials Analysis in the School of Chemistry, University of Birmingham for analytical services and Dr Louise Male for crystallographic analysis of 22. The authors thank $\mathrm{Dr} \mathrm{J}$. Wilkinson and Dr N. I. Ziedan for helpful discussions. The computations described in this paper were performed using the University of Birmingham's BlueBEAR HPC service, which provides a high-performance computing service to the University's research community. See http://www.birmingham. ac.uk/bear for more details.

\section{Notes and references}

1 P. Rajendran, T. Rengarajan, J. Thangavel, Y. Nishigaki, D. Sakthisekaran, G. Sethi and I. Nishigaki, Int. J. Biol. Sci., 2013, 9, 1057.

2 D. Versari, E. Daghini, A. Virdis, L. Ghiadoni and S. Taddei, Diabetes Care, 2009, 32, S314.

3 P. O. Bonetti, L. O. Lerman and A. Lerman, Arterioscler., Thromb., Vasc. Biol., 2003, 23, 168.

4 T. M. Paravicini and R. M. Touyz, Diabetes Care, 2008, 31, S170.

5 A. Ghosh, L. Gao, A. Thakur, P. M. Siu and C. W. K. Lai, J. Biomed. Sci., 2017, 24, 50.

6 F. Chevalier, M. Lavergne, E. Negroni, S. Ferratge, G. Carpentier, M. Gilbert-Sirieix, F. Sineriz, G. Uzan and P. Albanese, Stem Cell Res., 2014, 12, 703.
7 A. A. Birukova, T. Wu, Y. Tian, A. Meliton, N. Sarich, X. Tian, A. Leff and K. G. Birukov, Eur. Respir. J., 2013, 41, 165.

8 L. W. Chen, M.-C. Tsai, C.-Y. Chern, T.-P. Tsao, F. Y. Lin, S.-J. Chen, P.-F. Tsui, Y.-W. Liu, H.-J. Lu, W.-L. Wu, W.-S. Lin, C.-S. Tsai and C.-S. Lin, Br. J. Pharmacol., 2020, 177, 5375-5392.

9 A. Tamburrini, C. Colombo and A. Bernardi, Med. Res. Rev., 2020, 40, 495.

10 R. Hevey, Pharmaceuticals, 2019, 12, 55.

11 D. Pratesi, C. Matassini, A. Goti, A. Angeli, F. Carta, C. T. Supuran, R. Spanevello and F. Cardona, ACS Med. Chem. Lett., 2020, 11, 727.

12 L. Soria-Martinez, S. Bauer, M. Giesler, S. Schelhaas, J. Materlik, K. Janus, P. Pierzyna, M. Becker, N. L. Snyder, L. Hartmann and M. Schelhaas, J. Am. Chem. Soc., 2020, 142, 5252.

13 E.-A. Raiber, J. A. Wilkinson, F. Manetti, M. Botta, J. Deakin, J. Gallagher, M. Lyon and S. W. Ducki, Bioorg. Med. Chem. Lett., 2007, 17, 6321.

14 A. M. Mahmoud, F. L. Wilkinson, A. M. Jones, J. A. Wilkinson, M. Romero, J. Duarte and M. Y. Alexander, Biochim. Biophys. Acta, 2017, 1861, 3311.

15 A. M. Mahmoud, A. M. Jones, G. P. Sidgwick, A. M. Arafat, M. Y. Alexander and F. L. Wilkinson, Cell. Physiol. Biochem., 2019, 53, 323.

16 A. W. W. Langford-Smith, A. Hasan, R. Weston, N. Edwards, A. M. Jones, A. J. M. Boulton, F. L. Bowling, S. T. Rashid, F. L. Wilkinson and M. Y. Alexander, Sci. Rep., 2019, 9, 2309.

17 Y. Liu, T. Wang, J. Yan, N. Jiagbogu, D. A. Heideman, A. E. Canfield and M. Y. Alexander, Atherosclerosis, 2011, 219, 440.

18 D. M. Gill, L. Male and A. M. Jones, Eur. J. Org. Chem., 2019, 2019, 7568.

19 D. M. Gill, L. Male and A. M. Jones, Chem. Commun., 2019, 55, 4319.

20 A. M. Benedetti, D. M. Gill, C. W. Tsang and A. M. Jones, ChemBioChem, 2020, 21, 938.

21 J. A. Alshehri, A. M. Benedetti and A. M. Jones, Sci. Rep., 2020, 10, 16559.

22 H. C. Kolb, M. S. Van Nieuwenhze and K. B. Sharpless, Chem. Rev., 1994, 94, 2483.

23 M. Ultsch, N. A. Lokker, P. J. Godowski and A. M. de Vos, Structure, 1998, 6, 1383.

24 G. M. Morris, D. S. Goodsell, R. S. Halliday, R. Huey, W. E. Hart, R. K. Belew and A. J. Olson, J. Comput. Chem., 1998, 19, 1639.

25 L. D. Thompson, M. W. Pantoliano and B. A. Springer, Biochemistry, 1994, 33, 3831.

26 See ESI† page S6.

27 See ESI† page S7.

28 See ESI† page S8. 